\title{
ТЕОРИЈСКО-МЕТОДОЛОШКИ АСПЕКТИ ПРОУЧАВАњА СЛАВЕНОСРПСКОГ ЈЕЗИКА
}

\begin{abstract}
Иако славеносрпски језик, као књижевнојезички израз српског културног простора 18. и прве половине 19. века, представља етапу у развоју књижевног језика Срба од посебне важности, након победе вуковских књижевнојезичких поставки истраживањима овог изузетно комплексног језичког хибрида није посвећивана велика пажња. Тек од краја 19. и у првој половини 20. века славеносрпски језик полако почиње да постаје предмет научних истраживања да би своју пуну научну ренесансу остварио у другој половини 20. века, у радовима А. Младеновића, И. Грицкат, Ј. Кашића, Ј. Јерковића, П. Херитија, Љ. Суботић, А. Кречмер и др. Фокусирана на графију, ортографију, фонологију и морфологију, ова истраживања имала су најпре дескриптивни филолошки карактер и била удруживана са структуралнолингвистичким поставкама. Новија истраживања, међутим, бивају допуњена аналитичко-синтетичком, контекстуалном, те методом унутрашње и спољашње компарације, удруженом са новијим лингвистичким правцима, попут социолингвистике, лингвистике текста и др. У раду се даје синтеза досадашњих приступа проучавању славеносрпског језика, указује се на њихове предности и недостатке, те на смер будућих истраживања.

Кључне речи: теоријске поставке, методологија, славеносрпски језик.
\end{abstract}

0. Пре тачно тридесет година (1990), а поводом обележавања три деценије „истраживања славеносрпског доба” А. Кречмер је написала добро утемељену ретроспективу проучавања славеносрпског језика, у којој спроводи евалуацију добијених резултата и наводи своје виђење смера будућих (и пожељних) истраживања (Кречмер 1990).

Данас, након шездесет година интензивнијег проучавања овог књижевног језика, слика се у извесном смислу изменила и овај текст представљаће врсту још једног камена међаша како би се са дистанце дуге шест деценија (1) изнова сагледала теоријско-методолошка кретања у истраживању славеносрпског језика, (2) пружио преглед онога што се налазило у фокусу научне

\footnotetext{
*isidora.bjelakovic@gmail.com
} 
пажње, (3) дала синтеза досадашњих приступа у проучавању, (4) указало на њихове предности и недостатке, (5) те на смер будућих истраживања.

1. ТЕОРИЈСКЕ ПОСТАВКЕ И ДЕФИНИСАњЕ СЛАВЕНОСРПСКОГ ЈЕЗИКА. СаДа Већ давне 1966. године Ирена Грицкат је, указујући на неправедну запостављеност истраживања славеносрпског језика, истицала потребу за студиознијим приступом и потпунијом анализом овог књижевнојезичког идиома.

Међутим, упркос појави све већег броја лингвиста који су делили ово мишљење, јединственог става није било - пре свега у смислу општих поставки у вези са интерпретацијом његове генезе. С једне стране, И. Грицкат заступала је мишљење о својеврсној надградњи вернакулара као основног механизма у стварању овог језичког типа (1966: 65). ${ }^{1}$ Насупрот овој хипотези налазила се поставка о вернакуларизацији рускословенског језика, која је током наредних педесет година била готово свеприсутна и доминантна међу најистакнутијим проучаваоцима наведеног књижевног језика (в. Младеновић 1973; Дмитријев 1974; и др.). Поред тога, хронолошки оквир који се везује за егзистенцију славеносрпског језика у србистичкој литератури готово без изузетка подразумева период од средине 18. века до двадесетих година 19. века (или до његове средине ако се под славеносрпским подразумева и тзв. доситејевски тип језика - како ћемо га ми у овом тексту посматрати). Другачији, али прилично усамљен став имала је И. Грицкат, која је заступала идеју о томе да славеносрпски језик треба посматрати из шире хронолошке перспективе, у оквиру које он своју предисторију везује за 17. век, а добија основе током прве половине 18. века (1987: 113). Вишеслојност славеносрпске епохе, па и језика, она је посматрала из једне шире перспективе - културолошке, али и друштвено-политичке, не сматрајући га искључиво еманацијом просветитељских идеја друге половине 18. века. Чини се - у то време прилично далековидо и сасвим оправдано.

Наведено теоријско несагласје, очекивано, утицаће на методологију и циљеве потоњих истраживања: док у својим текстовима И. Грицкат углавном анализира специфичне књишке црте у славеносрпском језику (пратећи систем језичке надградње), представници поставке о вернакуларизацији рускословенског језика у фокус својих интересовања постављају или анализу степена присуства народних црта у славеносрпском, или њихов однос према књишким елементима. У оба случаја полази се од дескриптивне методе, која се удружује са структуралнолингвистичком поставком. ${ }^{2}$

2. ХРОНОЛОГИЈА И МЕТОДОЛОГИЈА ИСТРАЖИВАЊА СЛАВЕНОСРПСКОГ ЈЕЗИкА. Остављајући по страни овом приликом анализе славеносрпског језика у радовима П. Кулаковског, Т. Остојића, Ј. Скерлића, Б. Унбегауна, М. Суче-

\footnotetext{
${ }^{1}$ „Под славеносрпским треба подразумевати све оно што су људи од пера, почев од друге половине 18. до негде пред средину 19. века, надграђивали над свакодневним говором нешколованог света, над својим родним дијалектом или дијалектима" (Грицкат 1966: 65).

${ }^{2}$ Будући да је лингвистичка методологија тесно повезана са лингвистичким теоријама, не може се говорити о методологији, а да се из разматрања искључи њен теоријски оквир (Пипер 2000: 6).

Аналогна истраживања присутна су и у другим пољима проучавања српске језичке дијахроније (в. Павловић 2017).
} 
вића, А. Белића, М. Павловића и других аутора који су несумњиво заслужни за постављање фундаменталних знања и формирање опште слике о вези друштвено-политичког контекста и генезе овог језичког типа, овом приликом обратићемо већу пажњу на правце у истраживањима која су се реализовала управо од шездесетих година 20. века до данас.

2.1. ИСТРАЖИВАњА ГРАФИЈЕ И ОРТОГРАФИЈЕ. ИаКО Се У ЛИТераТУРИ ОД четрдесетих година 20. века срећу текстови посвећени традиционалној графији (пре свега, статусу појединих графема у писмености Срба 18. века), детаљнија анализа графијско-ортографских проседеа појединих аутора и/или њихових дела на славеносрпском језику започиње истраживањима А. Младеновића (1961: 136-148; и др.). Он у њима, наиме, поставља основна методолошка начела, која ће бити примењивана у низу каснијих истраживања.

Поред тога, немали број радова посвећен је проучавању реформисања традиционалне ћирилице, у којима се наводе најпроминентнија имена српског културног круга 18. века која су у мањој или већој мери уочавала потребу ка поједностављивању графијско-ортографских начела и имплицитно спроводила својеврсну реформу алфабета и/или ортографије. Посебну пажњу у текстовима овог профила добија реформа Саве Мркаља, који у радовима пре свега А. Младеновића и М. Окуке добија своју пуну ревалоризацију.

Коначно, знатан помак у истраживањима графије и ортографије славеносрпског језика реализован је почетком другог миленијума у низу радова посвећених овој проблематици. Међу њима посебну пажњу заслужују текстови А. Милановића, у којима се инвентар графема и тип алфабета (реформисан/традиционални) директно доводи у везу не само са књижевнојезичким поставкама појединих аутора (Мркаљ, Вук, Суботић и др.) него и са ванјезичким факторима, чиме се аргументовано указује на то да се једино контекстуализацијом ове врсте могу добити објективни одговори на питања структуре графијско-ортографских модела у 18. и 19. веку.

2.2. ИСТРАЖИВАњА ФОНОЛОГИЈЕ И МОРФОЛОГИЈЕ. АНалоГНа ситуација у хронолошком смислу затиче се и на пољу почетака проучавања фонологије и морфологије. Описујући, наиме, језичку структуру одабраних дела 3. Орфелина и J. Рајића, А. Младеновић анализира фонолошке и морфолошке карактеристике појединих текстова применом дескриптивне диференцијалне методе, типичне за дијалектолошка истраживања тог времена, а у духу структуралистичке поставке (Младеновић 1960; и др.). Оваквој методологији приступа се пре свега у тежњи да се докаже како су и писци предвуковци у високом степену писали народним језиком, а тиме и утицали на формирање будућег стандарда. Ипак, у наведеним истраживањима често се из вида губи шири контекст, па и чињеница да тај језик ипак није био у потпуности вернакуларан.

Седамдесетих и осамдесетих година 20. века настављају се истраживања заснована на истом теоријско-методолошком концепту у радовима А. Албина, Ј. Јерковића и др. да би их од деведесетих година бивало све мање.

2.2.1. Истовремено са применом наведене методологије, А. Младеновић 1969. године отвара и питање анализе структуре мешовитог језика појединих 
аутора 18. и 19. века, те уводи и примењује тзв. статистичку методу или методу упитника - статистички опис односа дистинктивних рускословенских/ руских, српскословенских и народних црта на фонолошком и морфолошком плану (1969). Већ 1970. године А. Младеновић (1970: 110-116) уводи и тзв. Упитник 2, у којем анализира нове дистинктивне фонетизме и морфолошке специфичности. Метода упитника наћи ће своју примену у низу каснијих истраживања како А. Младеновића тако и потоњих истраживача. Критички је посматрајући, А. Кречмер наводи неколико њених објективних недостатака: 1. упитник се односи пре свега на фонолошки и морфолошки ниво, док су синтакса и лексика готово потпуно занемарене; 2. он обухвата само дистинктивне црте, док заједничке карактеристике остају изван оквира анализе; 3. преводна књижевност није укључена у корпус иако је одиграла важну улогу у конституисању славеносрпског језика; 4. метода упитника је искључиво лингвистичка, а предмет анализе - језик одвојен од текста (Кречмер 1990: 222).

2.2.2. Оно што би свакако требало посебно истаћи јесте да све време, уз методу упитника, на широку примену наилази и споменута дескриптивна метода, у којој истина нема - због обима корпуса - статистички обрађених података, али која доноси далеко ширу лепезу информација о језику појединих аутора. Због тога, ако не већу, а оно исту заслугу треба приписати примени ове методе. Захваљујући њој данас имамо не само филолошке студије појединих дела него и монографске описе језика великих имена наше културне прошлости: Ј. Рајића (Младеновић 1964), Д. Обрадовића (Куна 1970); С. Новаковића (Албин 1968); Е. Јанковића (Херити 1983); М. Видаковића (Кашић 1968); Ј. Игњатовића (Јерковић 1972); Б. Атанацковића (Јерковић 1976); Ј. Хаџића (Суботић 1989); Ј. Стејића (Нуорлуото 1989); П. Соларића (Бабић 2012); Ј. Суботића (Милановић 2014).

2.2.3. Иако деведесете године 20. века доносе нове текстове посвећене анализи одређеног сегмента фонолошке / морфолошке равни текста (нпр. у радовима Г. Невекловског и др.), истраживања се, ипак, све више усмеравају ка синтакси и лексици.

2.3. ИСТРАЖИВАЊА СИНТАКСЕ. Сасвим очекивано, синтакси је у Првим истраживањима посвећено релативно мало пажње и она се у радовима из шездесетих и почетка седамдесетих година 20. века сводила на регистровање свега неколико карактеристика: предлошког инструментала у социјативном значењу, генитива блокираног предлогом за (нпр. за младости и сл.), конструкције за + инфинитив, на употребу инфинитива, словенског генитива, рекције нетипичне за савремени стандард (нпр. мрзети на неког), на употребу презента у функцији футура II (нпр. узмогнем и сл.), на површна запажања о положају енклитика, реда речи у реченици (препоновану/постпоновану позицију атрубута, његово одвајање од управне речи, финалну реченичну позицију предиката, на позицију глаголске допуне, и др.), на употребу предлога ради/због, везника будући да, док, премда, и др. (уп. Младеновић 1964: 134-146; Албин 1966; и др.).

Иако се седамдесетих година појављују прве студије посвећене искључиво синтаксичкој проблематици (нпр. у текстовима Ј. Кашића и Х. Куне), 
осамдесете године 20. века јесу оне које доносе видни заокрет ка истраживањима овог језичког нивоа. Синтакса није више представљала само финални сегмент језичке анализе дела појединих аутора. Она се од тада нашла у фокусу низа аналитичко-синтетичких проучавања Љ. Суботић, И. Грицкат, Ј. Ајџановић, И. Бјелаковић, А. Милановића и других аутора у чијем су фокусу биле следеће категорије: партиципи, реченична кондензација, барокна реченична структура, опкорачење, антепозиција неатрибутских речи, финална позиција глагола, инверзија, интерполације, релативна реченица, инфинитив, синтаксички паралелизам, кумулација, корелативи у зависносложеним реченицама, ред речи, конгруенција, деагентизована реченица и реченица са допунским предикативом, пасив, глаголска перифраза, семантика падежа и др. ${ }^{3}$

2.4. ТЕКСТОЛОшКЕ АНАЛИЗЕ. Осамдесете године доносе и нову - контрастивну текстолошку методу - у радовима П. Пипера и М. Бошков, чијом се применом пореде преводни текстови са оригиналом како би се указало на дистинкције, језичке утицаје и књижевнојезички развој појединих жанрова. Иако добро постављена и комплементарна методи упитника и дескриптивној методи, она није заживела у потоњим истраживањима, и среће се само спорадично, пре свега у радовима страних слависта.

2.5. ИСТРАЖИВАњА ЛЕКСИКЕ. СЛично ситУацији са синтаксом, напомене о лексици у првим истраживањима веома су ретке, оскудне и површне. Истичући важност проучавање лексике славеносрпског језика и апелујући на недопустиво мали број радова из историјске лексикологије, В. Михајловић објављује два лексикографска подухвата - Грађу за речник страних речи у предвуковском периоду (1972-1974) и Посрбице од Орфелина до Вука (19821984).

Иако се и седамдесетих и осамдесетих година спроводе интересантна истраживања лексике у текстовима Ј. Јерковића, И. Грицкат и др., деведесете године 20. века јесу оне које доносе нов замах у лексиколошко-лексикографским анализама да би оне биле интензивиране у новом миленијуму. Реч је о радовима И. Грицкат, Ј. Кашића, С. Стијовића, Љ. Суботић, А. Милановића, Р. Драгићевић, И. Бјелаковић, А. Мацановић, М. Зорић, и др. Наведена истраживања могу се поделити на следеће домене, у оквиру којих су примењене различите методе - аналитичко-синтетичка, дистрибутивна, концептуална, метода супституције, унутрашње и спољашње компарације и др.:

1. анализа процеса интелектуализације књижевног језика Срба у 18. и 19. веку, чија је једна од манифестација и лексичко принављање;

2. анализа терминолошког регистра;

3. регистровање и дериватолошка анализа славенизама у делима појединих аутора, уз спорадичну лексикографску обраду;

4. дериватолошка анализа лексема одређеног творбеног модела;

5. питања теоријске и практичне историјске лексикографије;

6. анализа лексичке спојивости, синонимије, фразеологије и др. 2017)

${ }^{3}$ Готово идентична ситуација потврђена је у дијахронијској србистици уопште (в. Павловић 
Иако су посвећена различитим видовима анализе лексикона, уз неколико изузетака, наведена истраживања имају углавном фрагментарни карактер, што је потпуно очекивано будући да је познато да је степен развоја историјске лексикологије у директној вези са степеном развоја историјске и етимолошке лексикографије, тј. зависи од броја и квалитета потпуних историјских и етимолошких речника. У том смилу, важно је нагласити да је израда речника славеносрпског језика један од приоритетних задатака дијахронијске србистике.

2.6. СОЦИОЛИНГВИСТИЧКА И НОВИЈА ИСТРАЖИВАњА. НаПоредо са Проучавањем језика славеносрпске епохе србистичка литература праћена је синтетичким текстовима посвећеним књижевнојезичкој ситуацији међу Србима у 18. и током прве половине 19. века. Реч о студијама А. Младеновића, И. Грицкат, П. Ивића, П. А. Дмитријева, Н. И. Толстоја, А. Албијанића, П. Херитија, Љ. Суботић, А. Кречмер, Б. Ћорића, М. Окуке, Р. Маројевића, А. Милановића, И. Цветковић-Теофиловић, И. Бјелаковић и других аутора у којима се

a. даје преглед типова књижевних језика;

б. анализирају ставови ондашњих аутора према књижевном језику, писму и правопису, чиме се често контекстуализује и појава Вука Караџића;

в. тумачи значење појмова с(е)рпски и славенос(е)рпски како у свести тадашњих аутора тако и у савременој науци;

г. објашњава генеза славеносрпског, његова хронологија, развој и структура;

д. анализира однос (конкуренције и коегзистенције) према рускословенском/руском и српском народном језику вуковског типа;

ђ. установљава жанровска структура текстова и истиче њен значај у одабиру језика;

е. проучава историја и развој граматографије код Срба у периоду до 1867. године;

e. анализирају методолошки принципи и/или се указује на пожељан смер будућих истраживања;

ж. указује на терминолошку неуједначеност.

2.7. Наведени текстови, посматрани из савремене перспективе, представљају истовремено и одличан извор за праћење теоријских поставки у вези са генезом и структуром славеносрпског језика, а самим тим, и методологијом истраживања овог језичког типа. У наглашавању потребе ка иновативнијем приступу А. Кречмер и Љ. Суботић истичу неопходност ка промени перспективе у истраживањима, која се не би сукобљавала са дотадашњим моделима анализе, него би више представљала његову надградњу будући да би била реализована на фону историје културе. У начелу, основна поставка подразумевала би методологију која би полазила од текста као целине, при чему би се у анализу укључивали како лингвистички тако и екстралингвистички фактори, а обрађивали би се сви језички нивои комплетном дескрипцијом грађе, без занемаривања функционалне компоненте. Поред анализе из 
перспективе спољашње историје језика, као пожељан наводи се и контрастивни приступ (на дијахроној оси - нпр. једног жанра; или у синхроном пресеку - анализа више жанрова једне епохен; и сл.) како би се применом панхроничке методе (односно синтезе свих добијених резултата) реконструисао развој датог књижевног језика или уочила паралела међу више словенских језика (пре свега Православне Славије), чиме би се изашло изван „усконационалних" оквира (в. Кречмер 1987; 2000; Суботић 2003).

У духу наведених ставова, истраживања новог миленијума доносе методолошки заокрет и нов замах у проучавањима славеносрпског језика. За разлику од традиционалнијих истраживања, у којима се тематика и жанровска профилисаност дела, те његова намена, статус адресата или читалачке публике, поставља у секундаран план, уз краће коментаре у виду напомена, новија истраживања у исту раван са језичком структуром постављају наведене елементе, укрштајући притом неколико теоријско-методолошких принципа. На тај начин, дескриптивна метода бива замењена аналитичко-синтетичком и контекстуалном, те методом унутрашње и спољашње компарације, уз ослонац на теоријске поставке социолингвистике, лингвистике текста и/или лингвостилистике, и њихову примену на репрезентативном корпусу. У фокусу истраживачке пажње, пре свега аутора млађе генерације - А. Милановића, И. Цветковић Теофиловић и И. Бјелаковић, сада се, између осталог, налазе поједини поджанрови (пословноправна писма, вести, некролози, тефтери), њихова језичка структурираност (дистрибуција књишких и вернакуларних елемената), те зависност типа језика одређеног документа од социолингвистичких фактора (социјалне стратификације учесника у комуникацији) и/или тематско-структурне устројености текста, однос језика и стила, односно стилистички аспект промена у књижевним језицима. Наведени заокрет доноси и прелаз са филолошких на лингвистичка истраживања.

3. ЗАКључАК. Теоријско-методолошки оквири истраживања славеносрпског језика од шездесетих година 20. века до данас указују на процес у којем се уочава пут од дескриптивне филолошке до аналитичко-синтетичке и контекстуалне лингвистичке методе, те методе унутрашње и спољашње компарације, које истовремено прати и удруживање са одговарајућим теоријским поставкама - од структуралистичке до социолингвистичке и лингвистике текста. Наведен развојни пут налази се у директној вези са добијеним резултатима и знањима о славеносрпском језику. За разлику, наиме, од деветнаестовековне провуковске идеологије о славеносрпском као хибридном, макаронском, хаотичном језичком амалгаму који је Вук са својим истомишљеницима сасвим оправдано одбацио, прогласио непожељним и - коначно - уклонио са књижевнојезичке сцене, шездесете године 20. века доносе значајан преокрет будући да од тада славеносрпски почиње све више да се посматра као незаобилазна карика у развоју књижевног језика Срба. Истина, он се не сагледава као један од сегмената јединственог дијахронијског лука, који почетну тачку везује за старословенски, а крајњу за вуковски језик, већ

${ }^{4}$ Овом се проблематиком у извесној мери (на текстовима 3. Орфелина) бавио В. П. Гудков (1973). 
као почетак, темељ онога што ће бити заокружено у другој половини 19. века у виду српског језичког стандарда. Рецентнија истраживања указују на висок степен зависности овог језика од социјалне стратификације учесника у комуникацији и/или тематско-структурне устројености текста.

У том кључу, а уз примену постојећих метода удружених са савременим лингвистичким поставкама, треба градити будућа истраживања.

\section{ЛИТЕРАТУРА}

Албин 1966: А. Албин, О језичким особинама Милошевићевог романа Прикљученија краља Аполона и његове кћери Тарсије, Прилози проучаваюу језика, 2, 41-54.

Албин 1968: А. Албин, Језик новина Стефана Новаковића (1792-1794), Нови Сад: Матица српска.

Бабић 2012: Б. Бабић, Ортографске и језичке карактеристике у штампаним дјелима Павла Соларића, Бања Лука: Универзитет у Бањој Луци.

Дмитријев 1974: П. А. Дмитриев, Русско-славянский и славяно-сербский языки и проблемы создания литературного языка на народной основе, Зборник Матице српске за филологију и лингвистику, 17/1, 63-70.

Грицкат 1966: И. Грицкат, У чему је значај и какве су специфичности славеносрпског периода у развоју српскохрватског језика, Зборник Матице српске за филологију и лингвистику, IX, 61-66.

Грицкат 1987: И. Грицкат, Још нека питања у вези са славеносрпском епохом, Јужнословенски филолог, XLIII, 111-135.

Гудков 1973: В. П. Гудков, О „славенском” языке Захария Орфелина, Becmник МГУ, 9, Филология 3, 46-51.

Јерковић 1972: Ј. Јерковић, Језик Јакова Игњатовића, Нови Сад: Матица српска.

Јерковић 1976: Ј. Јерковић, Језик Богобоја Атанацєовића, Нови Сад: Матица српска.

Кашић 1968: Ј. Кашић, Језик Милована Видаковића, Нови Сад: Матица српска.

Кречмер 1987: A. Kretschmer, Српски књижевни језик у деценијама пре Вука (језичка анализа славеносрпских текстова: проблеми и могућности), Научни састанак слависта у Вукове дане, 17/2, 139-149.

Кречмер 1990: A. Krečmer, Nekoliko napomena povodom 30-godišnjeg jubileja istraživanja slavenosrpskog doba, Зборник Матице српске за филологију и лингвистику, 33, 221-231.

Кречмер 2000: А. Кречмер, О књижевно-језичкој традицији до 1800. код Срба и Руса (размишљања о словенској историјској стандардизацији), Јужнословенски филолог, 56/1-2, 543-559.

Куна 1970: Herta Kuna, Jezičke karakteristike književnih djela Dositeja Obradovića, Djela, XXXVI, knj. 21, Sarajevo: ANUBIH.

Милановић 2014: А. Милановић, Језик Јована Суботића, Београд: Филолошки факултет. 
Михајловић 1972-1974: В. Михајловић, Грађа за речник страних речи у предвуковском периоду, I-II, Нови Сад: Матица српска.

Михајловић 1982-1984: В. Михајловић, Посрбице од Орфелина до Вука, I-II, Нови Сад: Матица српска.

Младеновић 1960: А. Младеновић, Прилог проучавању Орфелиновог језика, Зборник Матице српске за филологију и лингвистику, III, 53-173.

Младеновић 1961: А. Младеновић, Графијска и језичка испитивања рукописа Доситеја Обрадовића, Ковчежић, Прилози и грађа о Доситеју и Вуку, 4, 135-163.

Младеновић 1964: А. Младеновић, О народном језику Јована Рајића, Нови Сад: Матица српска.

Младеновић 1969: А. Младеновић, Однос између домаћих и рускословенских елемената у књижевном језику код Срба пре његове вуковске стандардизације, Зборник Матице српске за филологију и лингвистику, XII, $43-51$.

Младеновић 1970: А. Младеновић, О неким рускословенским и српскохрватским језичким особинама у Орфелиновом Магазину, Зборник Матище српске за филологију и лингвистику, XIII/1, 103-118.

Нуорлуото 1989: Juhani Nuorluoto, Jovan Stejić's Language, Helsinki: Slavica Helsingiensia 8.

Павловић 2017: С. Павловић, Српска историјска лингвистика на почетку XXI века, Јужнословенски филолог, LXXIII/3-4, 163-205.

Пипер 2000: П. Пипер, Методологија лингвистичких истраживања, Београд.

Суботић 1989: Љ. Суботић, Језик Јована Хаиића, Нови Сад: Матица српска.

Суботић 2003: Љ. Суботић, Критички приступ проучавању историје (српског) књижевног језика, Српски језик 8/1-2, 99-110.

Isidora Bjelaković

\author{
THEORETICAL AND METHODOLOGICAL ASPECTS OF STUDIES \\ OF SLAVENO-SERBIAN
}

\begin{abstract}
Summary
Although the Slaveno-Serbian language, as the standard idiom of Serbian cultural space in the $18^{\text {th }}$ and the first half of the $19^{\text {th }}$ century, represents a particularly important stage in the development of the standard Serbian language, the research of this exceptionally complex linguistic hybrid did not receive much attention after the victory of Vukovian principles of the standard language. It was only at the end of the $19^{\text {th }}$ century and in the first half of the $20^{\text {th }}$ century that Slaveno-Serbian was slowly becoming the subject of scientific research, while it enjoyed its complete scientific renaissance in the second half of the $20^{\text {th }}$ century in works by A. Mladenović, I. Grickat, J. Kašić, J. Jerković, P. Heriti, LJ. Subotić, A. Krečmer, et al. Focused on graphemics, orthography, phonology and morphology, this research primarily had a descriptive philological character and it was associated with structuralist linguistic principles. Recent research, however, has been supplemented by the analytic and synthetic method, the contextual method as well as the method of internal and external comparison associated
\end{abstract}


with newer linguistic fields, such as sociolinguistic, text linguistics, etc. In the paper, there is given a synthesis of existing approaches to the study of the Slaveno-Serbian language. Their advantages and disadvantages are pointed out including the course of future research.

Keywords: theoretical settings, methodology, Slavonic-Serbian language. 